\title{
Identification of Urban Park Quality in Taman Indonesia Kaya, Semarang
}

\author{
Intan Muning Harjanti \\ Diponegoro University, Semarang, Indonesia
}

Corresponding e-mail: intanmuning@live.undip.ac.id

\section{Article info:}

Received: 06-01-2020, Revised: 21-04-2020, Accepted: 22-04-2020

\begin{abstract}
Based on observations and the results of the analysis, it was shown that Taman Indonesia Kaya already fulfilled the quality park standards. In the aspect of needs, the comfort factor has been fulfilled by the presence of park benches and garden lights in good condition, the cleanliness factor has been fulfilled by the existence of trash with a sorting system, public toilets and disabled toilets in clean condition, health factors have been fulfilled with the presence of acid trees, pandanus leaves and canna flowers, and safety factors have been fulfilled with the availability of a monitor bench gazebo and lighting lamps that function optimally. In the aspect of rights, the accessibility factor has been fulfilled, because it has strategic location and in the city centre and traversed by the Trans Semarang route, the freedom of activity factor have been fulfilled by the existence of a fountain garden, cultural stage and green space, and the diversity of activity factors have been fulfilled by the existence of the Pandawa park, mural gates, fountain shows, cultural arts performances, and various paintings. In the meanings aspect, the place clarity factor is indicated by the presence of information boards and signage that are scattered in the corner of the park, and the sociability factor have been fulfilled by the many of spaces in the park area that can be used for socializing, such as: paving fields, sidewalks, green spaces, and the cultural stage.
\end{abstract}

Keywords: identification, urban park quality, Taman Indonesia Kaya

\section{Introduction}

Urban nature has an important role in creating cities that have sustainability in ecological and social aspects (Irvine et al., 2010). One of the urban properties that can improve temperature comfort in general is green infrastructure (Klemm, Heusinkveld, Lenzholzer, Jacobs, \& Van Hove, 2015). This is in line with the strategic implementation of urban green infrastructure, which can provide additional benefits as a decrease in air temperature, reduce pollution and biodiversity habitats (Norton et al., 2015). One implementation of green infrastructure is urban green space, which has great potential in shaping a healthy lifestyle for the community (Zhang, Yang, Ma, \& Huang, 2015). Green space usually consists of vegetation and it is associated with natural elements, but this is not always the case. The definition of green space is not single, but can be adjusted to the scope of the discussion. Because the meaning of the term green space can be understood across disciplines, cultures and contexts, depending on the interpretation of the green space used (Taylor \& Hochuli, 2017). One of the manifestations of green space is green open space. Urban green open space is very valuable, because it is an environmental resource that can have a positive impact on the quality of life and value of community property. Green open spaces are divided into public green open spaces and private green open spaces, where one type of public green open space in urban areas is urban parks (Permen PU No.5, 2008). Urban parks are more inclusive green spaces compared to nonurban green areas and can encourage social cohesiveness (Peters, Elands, \& Buijs, 
2010). As one type of public green space, urban parks are a form of social facilities managed by the city government so that parks are public facilities that must be provided by the city government (Sugiyanto \& Sitohang, 2017)

Indonesia is one of the countries in the Asian continent whose inhabitants are known to be friendly and easy to socialize. In activities, the majority of the population interacts directly with each other, so that the urban park can be one of the spaces that can be used as a place to socialize and interact with the city residents. The city of Semarang is the capital of Central Java Province which is currently being intensively providing urban green open space, especially urban parks. Some urban parks in Semarang City include Bubakan Park, Raden Saleh Park, Gajah Mungkur Park, Mpu Tantular Park, Progo Park, Pandanaran Park, Macro Park, Jatisari Park, Kaya Indonesia Park, Simpang Lima Field (Housing and Settlement Office Semarang City, 2018). Taman Indonesia Kaya was chosen as the study area because this park is a park that can give a new color to the city of Semarang. Besides Taman Indonesia Kaya has a cultural stage, the stage became the first open cultural stage in Central Java (TribunJateng, 2018).

The purpose of this study is to determine the quality of Taman Indonesia Kaya as a quality urban park, by looking at the standard components that must be available in an urban park. The initial step of this research is to synthesize theories related to quality components of quality urban parks. After that the primary observation is carried out in the field to find out the conditions and availability of the determinant components. Then a qualitative descriptive analysis is carried out to identify whether Taman Indonesia Kaya fulfilled the components of a quality urban park.

\section{Methods}

The approach used in this research is a qualitative approach that is carried out inductively. A qualitative approach was used because this research was conducted by describing the empirical conditions in the field which were adjusted to the components of a good urban park. While the inductive view is used in this study because the findings related to good park quality standards at the study site will be produced at the end of the research process.

Data collection methods used in this study are secondary data collection methods and primary data. Secondary data collection is done by synthesizing theories that will be used to identify quality urban parks. Whereas primary data collection is done by direct field observations related to the components that form quality urban parks in Taman Indonesia Kaya.

\section{Results and Discussion}

Identification of quality urban parks, in this study using indicators of the availability of urban park components. The component of a good urban park is determined by synthesizing theory, that is according to the theory of (Carr, Rivlin, Francis, \& Stone, 1992), which explains that the components that can shape the quality of the quality of public spaces, namely: (1) aspects of needs (needs), which includes comfort, cleanliness, health and safety; (2) the right aspect, which includes accessibility / ease of achievement, freedom of activity, and diversity of activities; and (3) aspects of meaning (meanings), which include the clarity of place (legability) and the availability 
of space that can be a place to socialize between individuals and community groups (sociability).

According to the research conducted by (Pratomo, Soedwiwahjono, \& Miladan, 2019) , comfort factors in the aspects of needs can be identified from the quality of seating facilities, garden lights and public telephones, cleanliness factors can be identified from the availability of trash and public toilets, health factors are identified from types of vegetation available, and safety factors can be identified from the availability of gazebos and garden lights. While the factor of freedom of activity on the right aspect can be identified from the presence of play facilities, accessibility factors can be identified from the ease of achieving urban park locations and the diversity of activity factors can be identified from the many types of activities from the availability of its facilities. As well as the clarity of place factors in the aspect of meaning (means) can be seen from the presence of signage / directions in urban parks, and sociability factors that are identified from the availability of places or containers that can be used to socialize users.

\subsection{Needs Aspect}

Factors on aspects of needs that can form a good quality urban park, include: comfort, relaxation, active involvement, passive involvement.

\subsubsection{Convinience}

The comfort factor in the realization of quality urban parks can be identified from the availability of seating facilities, garden lights and public telephones.

\section{a. Park Seating/ Bench Facilities}

Park bench facilities provided in this park serve as a place for visitors to sit in social interactions such as sitting relaxed, chatting and so forth. In addition, visitors can enjoy the atmosphere of the park while sitting relaxed with friends and family. Park benches in Taman Indonesia Kaya consist of park benches made of iron, ordinary wood and cement, in accordance with SNI 19-7108-2005 concerning the standards of garden tables and chairs made not of teak wood. In addition, park benches are also spaced out and scattered at several points. This is in line with (Rutledge, 1981), which explains that everyone who sits in a park tends to choose to have a distance from each other, so the laying of a park bench must also accommodate these physical needs. Park benches in Taman Indonesia are rich in good condition with paint that looks white and clean, good wood condition and not porous, and clean cement benches. So that the availability of park benches has been fulfilled and in good condition, where the park bench is one of the minimum facilities that must be in the park (Pekerjaan Umum, 2008)
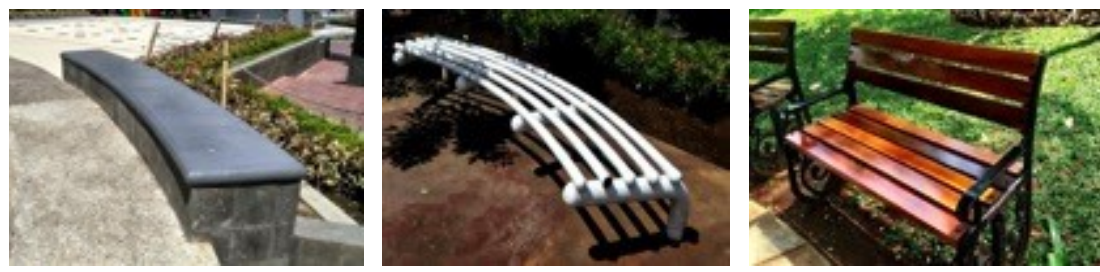

Figure. 1. Park Bench at Taman Indonesia Kaya (Observation, 2019) 


\section{b. Garden Lights}

Garden lights are supporting facilities for urban parks. In meeting the comfort factor, garden lights play an important role as garden lighting at night. Aside from being a garden lighting, it also functions to beautify the park. So that visitors feel comfortable visiting the urban park, even at night. Because the availability of parks arranged in such a way can provide a special attraction for visitors, especially for photo facilities. Taman Indonesia Kaya has three types of garden lights scattered in the park area. So that the availability of garden lights in this park already provides comfort to visitors and is in good condition. This is in line with (Wibowo \& Ritonga, 2018) which explains that the park lights become one of the minimal facilities that must exist in a city park.
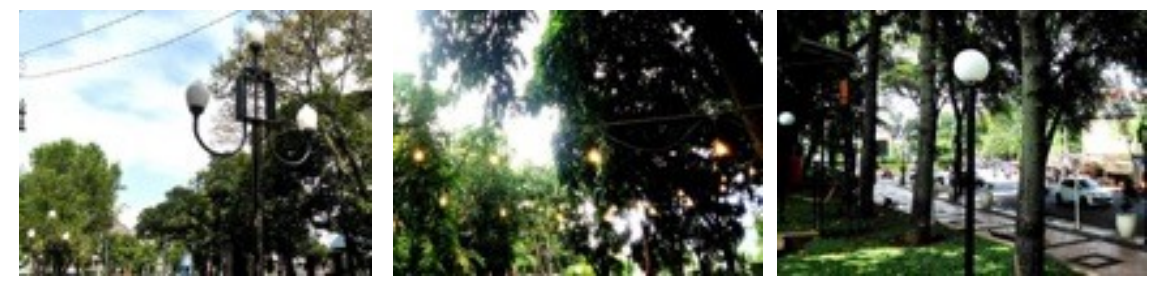

Figure. 2. Garden Lights at Taman Indonesia Kaya (Observation, 2019)

\section{c. Public Telephone}

Public telephone at Taman Indonesia Kaya is not yet available. This is in view of technological developments that have implications for people's lifestyles, where public telephone operations, both card public phones, tend to decrease from year to year, caused by damage to devices due to lack of maintenance and increased growth of cordless phones (Telecommunication Statistics in Indonesia 2015, 2015). So that almost all park users turn to communication devices such as mobile phones, which implies the need for less public telephones in urban parks. So even though this public telephone is not yet available, it does not affect user activity nor does it reduce comfort because the majority of visitors already have communication tools and this telephone availability is not needed.

\subsubsection{Cleanliness}

\section{a. Availability of Trash Can}

The availability of this trash can intended to maintain the cleanliness of the park by means of visitors who come not to litter. There are three types of plastic and zinc bins in Taman Indonesia Kaya. Based on field observations, one type of trash can in this park is a garbage container with the concept of organic and anorganic sorting. This is in line with (Damanhuri, 2010), which explains that the ideal waste container is adjusted to the type of waste (organic / anorganic or hazardous material), which aims to facilitate the next stage of processing. Bins that have been available at Taman Indonesia Kaya have been fulfilled and sufficient, with clean, good conditions and neatly arranged. In addition, there are garbage containers made of plastic and metal in the form of boxes and cylinders, which are procured by the management agency. This is in accordance with SNI 19-2454-2002, which explains that the characteristics of garbage containers in 
communal spaces are in the form of boxes or cylinders and covered, with a lightweight nature (easily moved), which are made of plastic or metal and are procured by the management agency.
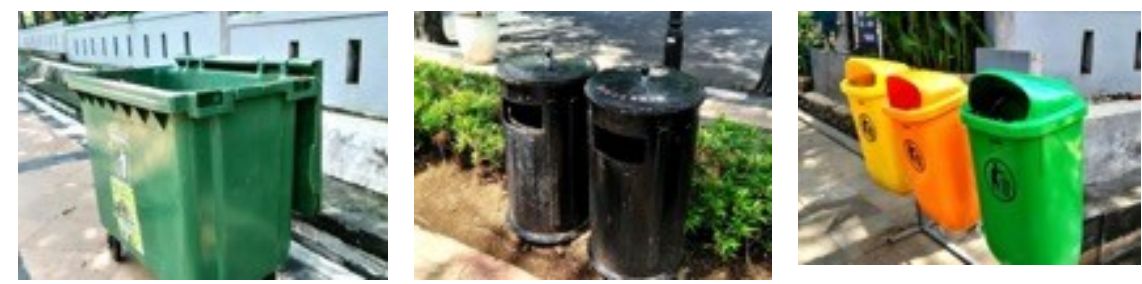

Figure. 3. Trash Can at Taman Indonesia Kaya (Observation, 2019)

\section{b. Availability of Public Toilets}

The availability of public toilets in the urban park area can increase the sense of comfort for visitors to visit longer in the park. Besides public toilets in Taman Indonesia Kaya, there are also available toilets for visitors with disabilities. It is expected that the diffable also get the same service to get comfort while visiting Taman Indonesia Kaya. Public toilets and disabled toilets are next to the cultural stage, where people with disabilities also have the right to get good access in public spaces because public facilities such as parks must be able to apply universally including those with disabilities (Dewang, 2010). Based on field observations, the condition of toilets in Taman Indonesia Kaya has been fulfilled and is in good and clean condition. This is because the toilet is routinely cleaned by officers every day, so the toilet always looks clean and fragrant as well as visitors feel comfortable to use it and stay longer in the park. This is in line with (Alfrida, 2019), which states that public toilets can affect visitor satisfaction in public spaces.
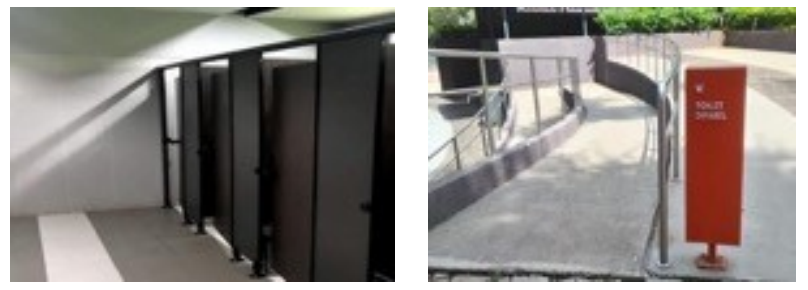

Figure. 4. Public Toilets at Taman Indonesia Kaya (Observation, 2019)

\subsubsection{Health}

\section{a. The Availability of Vegetation Types}

One component that affects the health factor of urban park users is the type of vegetation. Vegetation is the most important factor for urban parks, where vegetation acts as a producer of oxygen, regulating temperature, shade, reducing air pollution and aesthetic elements in urban parks. In addition, vegetation types and patterns are recreational, visual and ecological resources (De Chiara \& Koppelman, 1997) as well as the composition and diversity of vegetation can affect the function and benefits of a urban park (Zoer'aini, 2005). As an active 
urban park, Taman Indonesia Kaya has various types of vegetation. However, existing vegetation is more dominated by greenery and flower plants. During the day visitors usually sit relaxed in the green garden area. In the park area there are many plants and trees that can produce oxygen so that visitors can enjoy the cool air and create a microclimate, such as tamarind trees and pandan leaves. Tamarind tree is one type of vegetation that can show the identity of the City of Semarang, which is in line with (Nurisjah, 1991) inside (Widiastuti, 2013) which states that the selection of plants in a landscape one of the considerations must be able to pay attention to the value of certain identities. In addition, the diversity of space, including the density of vegetation, can produce social interaction behavior in the park (Rasidi, Jamirsah, \& Said, 2012).
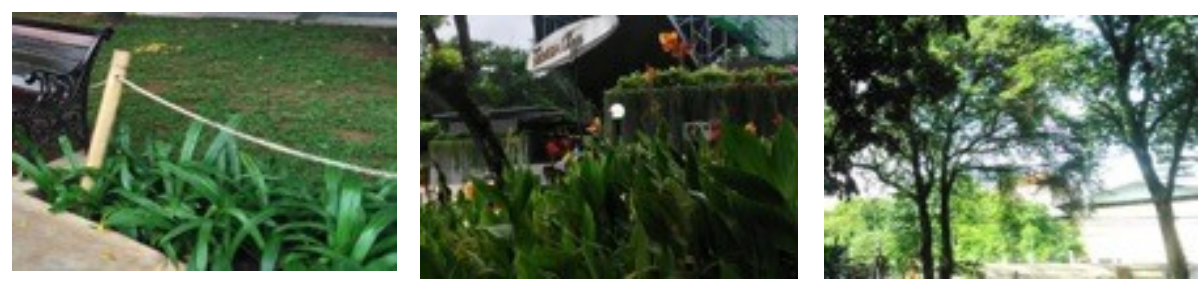

Figure. 5. Vegetation Types at Taman Indonesia Kaya (Observation, 2019)

\subsubsection{Safety}

\section{a. The Availability of Gazebo}

The availability of the gazebo as a security tool is already available at Taman Indonesia Kaya. Gazebo in this park can be used by visitors to unwind, especially senior visitors who prefer to enjoy a friend's vacation by sitting in the gazebo. This is in line with (Huang \& Huang, 2019), whose find that public facilities in city parks that are most often used by the elderly one of which is a gazebo. In addition, the gazebo in this park is also used as a guard post and there are also a monitor bench that works to monitor various user activities in the park area. The bench has a high position like the referee bench, which is used by security officers to monitor various activities and anticipate crime in the park area, where only security officers are permitted to occupy the bench.
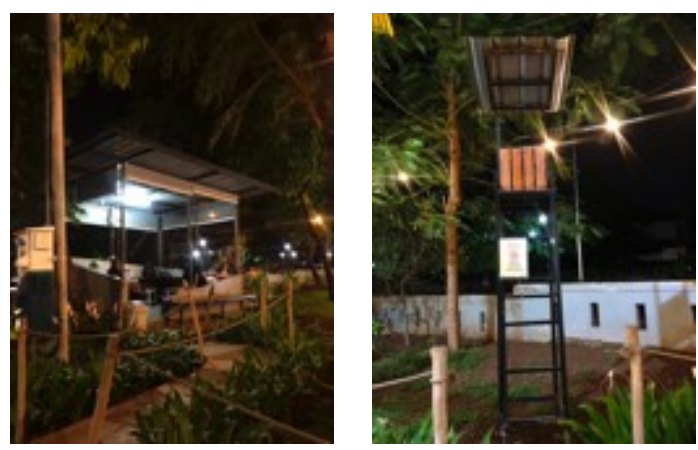

Figure. 6. Gazebo and Bench Monitor at Taman Indonesia Kaya (Observation, 2019) 


\section{b. The Availability of Lighting at the Park}

The availability of garden lights in fulfilling the safety factor in Taman Indonesia rich has been fulfilled. In this park there are several types of garden lights that emit bright and well-functioning rays, which are located in every corner and in the middle of the park. So that at night the park users can still do activities as usual in this park. This is in line with (Moyer, 1992), which states that an urban landscape at night is very dependent on lighting lights that can make it more attractive or even normal. Conversely, if the lighting in a city landscape is not good, causing beauty can not be enjoyed at night and reduce the visual quality and character (Starke \& Simonds, 2013). In addition, lighting can provide safety, security, orientation, promotion, identity, ambient lighting, and entertainment functions (Khrisna, 2008).
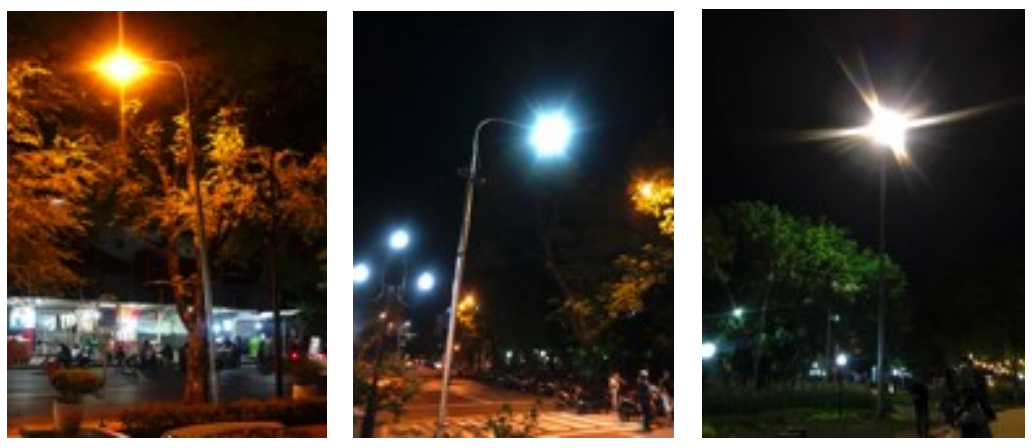

Figure. 7. Lighting at Taman Indonesia Kaya (Observation, 2019)

\subsection{Rights Aspect}

Factors in the aspect of rights that can shape good quality urban parks include: accessibility, freedom of activity, and diversity of activities.

\subsubsection{Accessibility}

\section{a. Ease of Achieving Urban Park Locations}

Taman Indonesia Kaya is located in Mugassari Sub-District, South Semarang District, Semarang City. Access to get to the Indonesia Rich Park can pass Pandanaran Street, Semarang-Surakarta Street and Menteri Supeno Street. The traffic is not too heavy and its location in the middle of the city, makes this park easy to access. Visitors who want to visit Taman Indonesia Kaya can use private modes of transportation such as motorbikes and cars as well as public transportation. In addition, visitors can also order vehicles based online. And for parking circulation space, visitors can park their vehicles across the street, for example in front of the Central Java Governor's Office and other locations that have become parking bags. This is in line with (Siahaan, 2010), which states that access to open space has the stability of accessibility easily that open space to reach. 


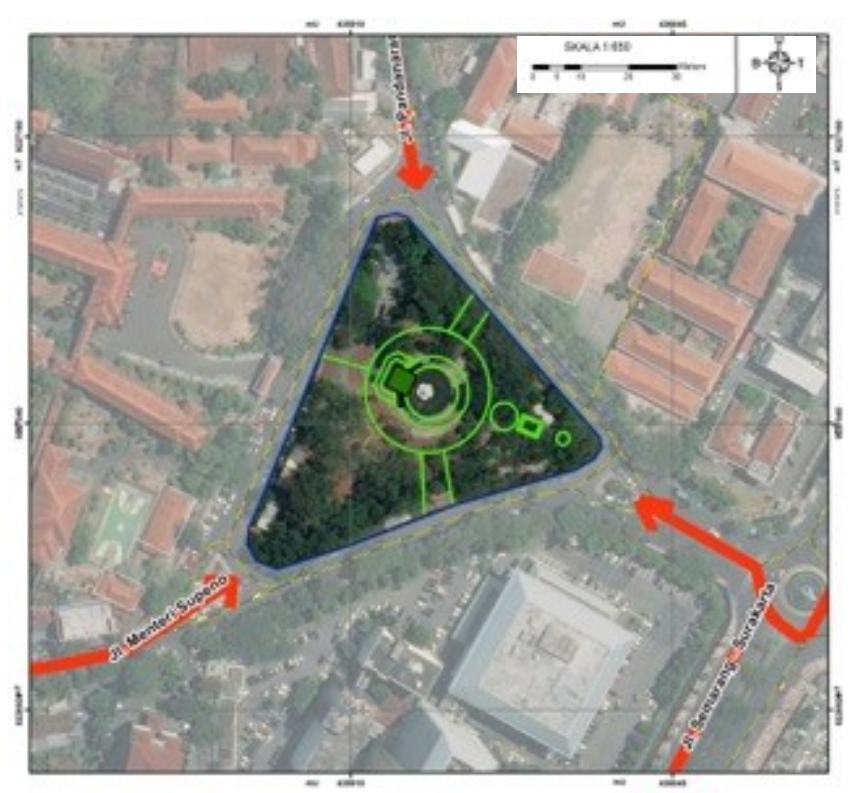

Figure. 8. Accessibility Map of Taman Indonesia Kaya (Analysis, 2019)

\subsubsection{Freedom of Activity}

\section{a. Availability of Play Facilities}

Play facilities at Taman Indonesia Kaya are in the form of a fountain, a cultural stage and a lounge. Around the fountain children are usually used to play water, while the cultural stage when not being used for shows, children use to play together, because it is a roomy and open space, so that when playing, children remain in custody her parents. In addition, there is also a lounge in the form of a green space, where children can play bikes, rollerblading, or play traditionally. As an active park, Taman Indonesia Kaya has been able to meet the park design criteria in general, where one of the criteria is the availability of space for children's play (Marcus \& Francis, 1998). This is in line with Suharto (1994) which explains that active parks are used by users to do activities to obtain pleasure, freshness and fitness, one of which can be realized in the form of play facilities.
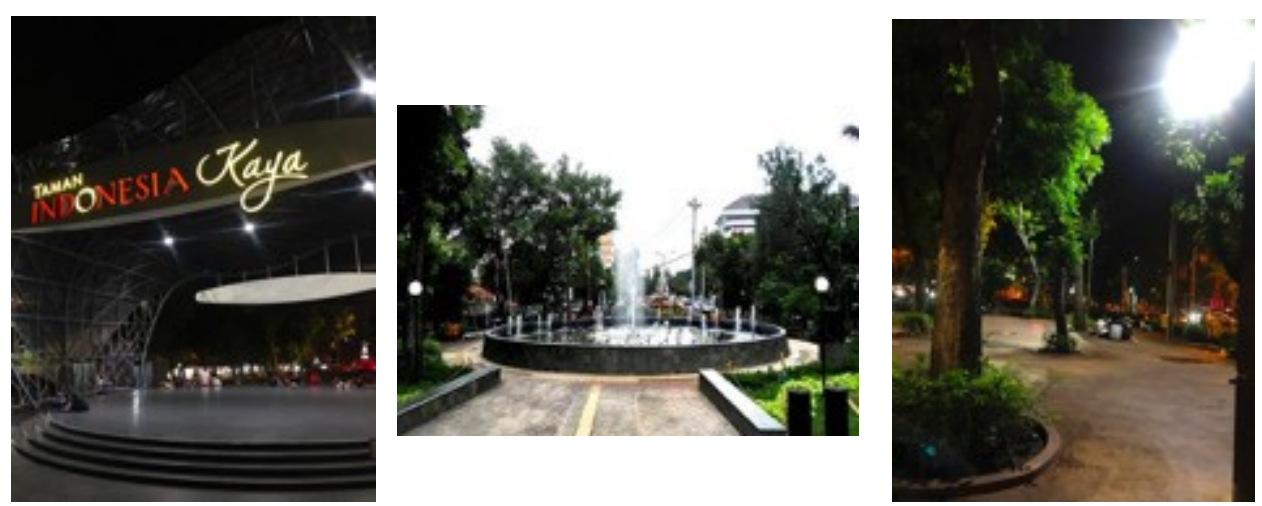

Figure. 9. Play Activities at Taman Indonesia Kaya (Observation, 2019) 


\subsubsection{Variety of Facilities}

\section{a. Many Types of Activities in Urban Park}

Taman Indonesia Kaya is one of the public green open spaces in urban park types. Besides being able to walk - enjoy the atmosphere of the park, visitors can also enjoy serving cultural art performances on certain days on the cultural stage, such as: keroncong music, gamelan music, traditional dances and so forth. Because the main purpose of the development of Taman Indonesia Kaya is as a forum for artists to express their art. In addition, visitors can also take pictures with a mural gate in one corner of the park, because the placement of public art in city parks can stimulate active contact and increase social interaction (Lukito \& Zahra, 2018). Besides, in this park visitors can recognize some puppet figures in the Pandawa park as an educational tool, enjoy the fountain show held on a certain schedule, and can enjoy selected paintings produced by students Semarang city, which is displayed in several points of the park. This is in line with (Gani, 2017) which mentions various activities that can be done in the park, including: outdoor learning, hanging out with friends, family recreation, watching together, children playing, and so on.
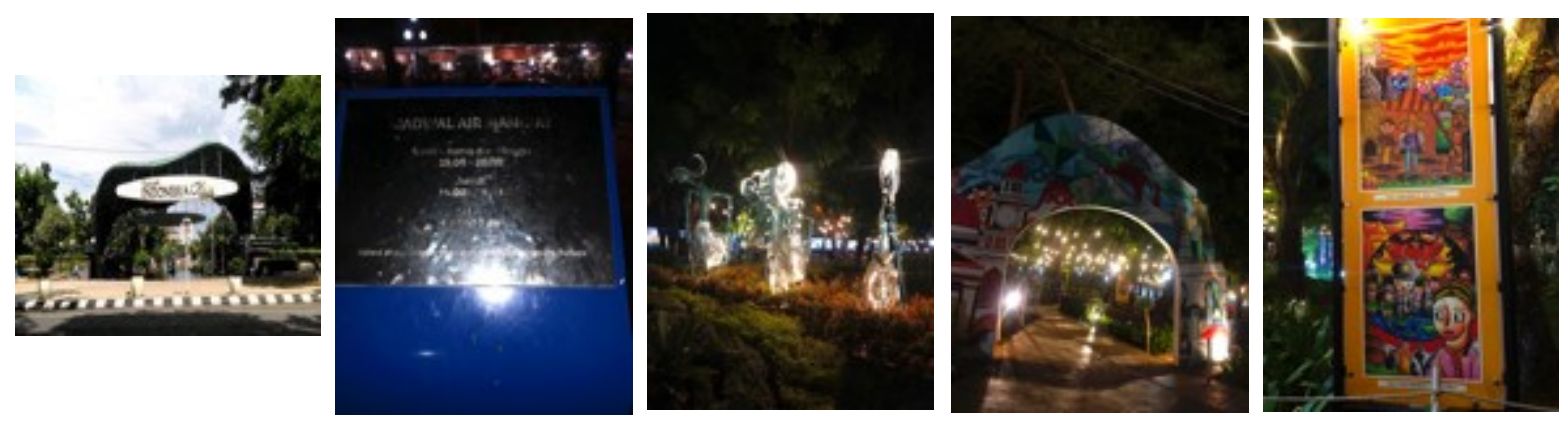

Figure. 10. Types of Activities at Taman Indonesia Kaya (Observation, 2019)

\subsection{Meanings Aspect}

Factors in the meanings aspects that can form a good quality urban park, including: clarity of place (legability) and the availability of space that can be a place to socialize between individuals and community groups (sociability).

\subsubsection{Clarity of Place}

\section{a. Availability of Signage at Urban Park}

Taman Indonesia Kaya has been equipped with a regional signage, where there are signposts and information provided in several corners of the park and with an attractive design. Like the pointer for the distribution of existing locations in the park, park direction indicators, and information boards related to park regulations. The visitor's location is easily accessible locations - locations of space that are scattered in Taman Indonesia Kaya and various facilities available. Signage on urban parks are important in directing and providing information to visitors, according to which (Tinarbuko, 2008). Signage is a series of visual and symmetrical graphical representations that function as a medium of interaction between humans and public space, which can be information 
markers, direction signs, orientation markers, and prohibitions or commands in certain areas (Gibson, 2009).
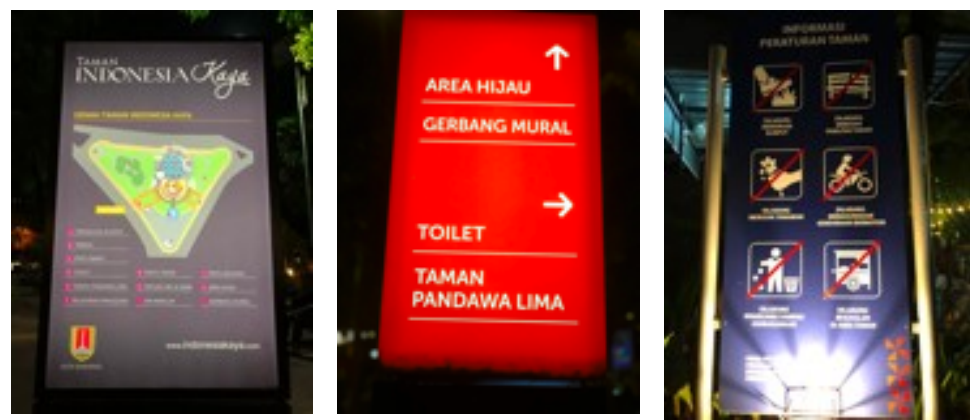

Figure. 11. Signage at Taman Indonesia Kaya (Observation, 2019)

\subsubsection{Sociability}

\section{a. Availability of Place to Socialize}

Taman Indonesia Kaya, was established with the main objective as an active public urban park that functioned to accommodate social activities of the community. So that in this park, almost all spaces can function as spaces for socializing, for example: paving grounds, sidewalks, green spaces, and cultural stages. Paving field is located in the middle of the park which is designed like a grandstand, where in addition to being used to watch a performance show, it can also be used to gather together. The sidewalk that functions as a pedestrian facility can also be used as a means of socializing, because in addition to its wide size, there are also park benches on its sides, so that visitors can use it for chatting together. This is in line with (Pratiwi, 2016) which states that the pedestrian function is transformed from time to time, which is not only for walking but also functions as a space for socializing. The green space of the park can be used as a socializing space because there are winding roads and park benches that can be used by visitors to enjoy the beauty of the park's vegetation and the atmosphere of the park, while chatting and doing activities together. Because sitting groups in the park can be used as a container for social interaction, especially those surrounded by shade trees (Jamila, 2019). Besides, the cultural stage which is also a landmark of Taman Indonesia Kaya, can also be used as a means of socializing place, where the performance space can also function as a symbol of interaction, especially the interaction between the performers and the audience (Salayanti, 2017).
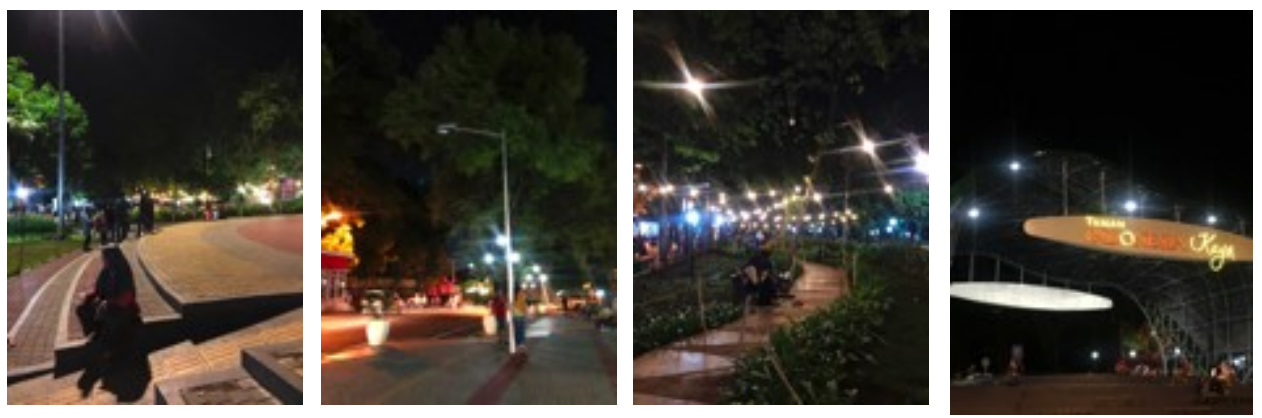

Figure. 12. Place to Socialize at Taman Indonesia Kaya (Observation, 2019) 
Green space offers a variety of facilities ranging from ecological services to recreational benefits, so that the impact of increasing city parks as social spaces (Choumert \& Cormier, 2011). Based on the identification results related to quality city parks, shows that city parks have an important role in supporting the social life of the community especially in urban areas. This is in line with (Gani, 2017) which states that urban parks with various concepts such as: smart gardens, green city parks, etc., can help develop social values in the lives of rural and urban communities that are increasingly eroded. Supported with (Peters et al., 2010) which explains that urban parks are places where various ethnic groups gather and mingle so as to stimulate the emergence of social cohesion, which is outlined in the design of parks and social interactions that play a role in uniting people in the community, especially in a multicultural context (Jamirsah, Said, \& Rasidi, 2011). So city parks have complex meanings in our lives, such as: (a) providing a social context that encourages moral goodness, (b) helps create a safe and stable community, and (c) increases the possibility of people to contemplate in their spare time (Kim, Lopez Frias, \& Dattilo, 2020).

\section{Conclusion}

Taman Indonesia Kaya is a public green open space of a urban park that is being sought after by the community, because of its attractive design and the many supporting facilities available. Based on observations and analysis results, it is shown that Taman Indonesia Kaya has generally met the quality standards of the park. In the aspect of needs, the comfort factor has been fulfilled by the presence of park benches with good conditions and diverse designs that are scattered in the park area, as well as the availability of well-functioning garden lights and attractive designs that are spread evenly in every corner of the park, and although public telephones are not available in this area but does not affect the comfort of visitors because the majority of visitors already have a personal communication tool. The cleanliness factor has been fulfilled by the existence of a trash can with a sorting system with clean conditions and is spread throughout the park area, and the availability of public toilets with clean conditions and also provided special toilets with disabilities. The health factor has been fulfilled by the presence of tamarind trees and pandan leaves which function to create a cool atmosphere in the garden area and the presence of canna flower plants as a relieving fatigue due to attractive flower plants. And the safety factor has been met with the availability of gazebos and monitoring bench that are used to monitor various activities of park visitors and anticipate crime, as well as the existence of park lighting lights that function optimally so that visitors feel safe and comfortable in visiting at night. In the aspect of rights, the accessibility factor has been fulfilled, with the ease of the location of the park to be reached either by using private vehicles or public vehicles because of its strategic location in the middle of the city and through the Trans Semarang lane. The freedom of activity factor is fulfilled by the presence of a fountain, cultural stage and green space that can be used freely by visitors. The diversity of activity factors have also been fulfilled by the existence of the Pandavas park, mural gate, fountain show, cultural art performance, and various paintings. In the meanings aspect, the place clarity factor is indicated by the presence of information boards and signposts that are scattered in the corner of the park. While the sociability factor can be seen from 
the number of spaces in the park area that can be used to socialize, where almost all the spaces in Taman Indonesia Kaya can be used as a means of socializing, such as: paving fields, sidewalks, green spaces, and the cultural stage.

\section{References}

Alfrida, V. dan N. A. (2019). Pengaruh Kualitas Layanan Toilet Saga Mall Abepura Terhadap Tingkat Kepuasan Pengunjung. JUMABIS, Vol. 3, 22-28.

Badan Standarisasi Nasional. 2005. SNI 19-7108-2005. Meja dan Kursi Taman dari Kayu Bukan Jati. Jakarta: Badan Standarisasi Nasional.

Badan Standarisasi Nasional. 2002. SNI 19-2454-2002. Tata Cara Teknik Operasional Pengelolaan Sampah Perkotaan. Jakarta: Badan Standarisasi Nasional.

Carr, S., Rivlin, L., Francis, M., \& Stone, A. (1992). Public Space. Australia: Cambridge Uiversity Press.

Choumert, J., \& Cormier, L. (2011). The provision of urban parks: An empirical test of spatial spillovers in an urban area using geographic information systems. Annals of Regional Science, 47(2), 437-450. https://doi.org/10.1007/s00168-010-0366-8

Damanhuri, E. (2010). PENGELOLAAN SAMPAH. Retrieved from https://s3.amazonaws.com/academia.edu.documents/31175121/diktatsampah2010-bag-1-

3.pdf?AWSAccessKeyld=AKIAIWOWYYGZ2Y53UL3A\&Expires $=1542184049 \&$ S ignature=Urm\%2FzD2\%2BzR4\%2BBOq5yKIQozodXkw\%3D\&response-contentdisposition=inline\%3B filename\%3DPengelolaan_Samp

De Chiara, J., \& Koppelman. (1997). Standar Perencanaan Tapak. Jakarta: Erlangga.

Dewang, N. (2010). Aksesibilitas Ruang Terbuka Publik Bagi Kelompok Masyarakat Tertentu Studi Fasilitas Publik Bagi Kaum Difabel Di Kawasan Taman Suropati Menteng-Jakarta. Jurnal PLANESA, 1(1), 8-18.

Dinas Perumahan dan Permukiman. 2018. Data Taman Kota di Kota Semarang. Semarang: Dinas Perumahan dan Permukiman

Gani, R. (2017). TAMAN KOTA SEBAGAI MODAL SOSIAL DAN INTERAKSI MASYARAKAT KOTA BANDUNG Rita Gani. Jurnal Signal Unswagati Cirebon, 5(1), 1-11.

Gibson, D. (2009). The Wayfinding Handbook. New York: Princeton Architectural Press.

Huang, T.-Y., \& Huang, C. (2019). Study on the Preference of Senior Citizens in Urban Park Public Facilities. PEOPLE: International Journal of Social Sciences, 5(1), 938-951. https://doi.org/10.20319/pijss.2019.51.938951

Irvine, K. N., Fuller, R. A., Devine-Wright, P., Tratalos, J., Payne, S. R., Warren, P. H., ... Gaston, K. J. (2010). Ecological and Psychological Value of Urban Green Space BT - Dimensions of the Sustainable City (M. Jenks \& C. Jones, eds.). https://doi.org/10.1007/978-1-4020-8647-2_10

Jamila, R. F. (2019). Tingkat Kenyamanan Taman Honda Tebet Sebagai Ruang $\begin{array}{llll}\text { Interaksi Sosial. } & \text { Vitruvian, } & 8(3), & \end{array}$ https://doi.org/10.22441/vitruvian.2019.v8i3.007

Jamirsah, N., Said, I., \& Rasidi, H. (2011). Social interaction among urban residents in greenspaces of New Township, Malaysia. Proceedings - 3rd International 
Postgraduate Conference on Infrastructure and Environment, IPC 2011, 2(1998), 746-751.

Khrisna, A. (2008). Konsep Pencahayaan ( Lighting ) Pada Lanskap Jalan Lingkar. Jurnal Lanskap Indonesia, 8(5), 716-724. https://doi.org/10.1371/journal.pone.0061460

Kim, J., Lopez Frias, F. J., \& Dattilo, J. (2020). Urban parks as spaces to pursue virtuous character, friendship, and contemplation: An Aristotelian perspective. Journal of Leisure Research, 51(1), 107-123. https://doi.org/10.1080/00222216.2019.1637703

Klemm, W., Heusinkveld, B. G., Lenzholzer, S., Jacobs, M. H., \& Van Hove, B. (2015). Psychological and physical impact of urban green spaces on outdoor thermal comfort during summertime in The Netherlands. Building and Environment, 83, 120-128. https://doi.org/10.1016/J.BUILDENV.2014.05.013

Lukito, Y. N., \& Zahra, R. A. (2018). Improving the Quality of Urban Lives through Public Art in Taman Suropati, Jakarta. IOP Conference Series: Earth and Environmental Science, 213(1). https://doi.org/10.1088/1755-1315/213/1/012030

Marcus, C. C., \& Francis, C. (Architecture and L. A. U. of C. (1998). People Places (Second; C. C. Marcus \& C. (Architecture and L. A. U. of C. Francis, eds.). Canada: John Wiley \& Sons, Inc.

Menteri Pekerjaan Umum. 2008. Peraturan Menteri Pekerjaan Umum No. 05/PRT/M/2008 Tentang Pedoman Penyediaan dan Pemanfaatan Ruang Terbuka Hijau di Kawasan Perkotaan. Jakarta: Menteri Pekerjaan Umum.

Moyer, J. . (1992). The Landscape Lighting Book. Newy York: John Wiley \& Sons, Inc.

Norton, B. A., Coutts, A. M., Livesley, S. J., Harris, R. J., Hunter, A. M., \& Williams, N. S. G. (2015). Planning for cooler cities: A framework to prioritise green infrastructure to mitigate high temperatures in urban landscapes. Landscape and Urban Planning, 134, 127-138. https://doi.org/10.1016/J.LANDURBPLAN.2014.10.018

Peters, K., Elands, B., \& Buijs, A. (2010). Social interactions in urban parks: Stimulating social cohesion? Urban Forestry and Urban Greening. https://doi.org/10.1016/j.ufug.2009.11.003

Pratiwi, Y. (2016). Transformasi Fungsi Ruang Terbuka Publik Di Perkotaan Studi Kasus: Taman Pedestrian Kecamatan Tenggarong, Kabupaten Kutai $\begin{array}{llll}\text { Kartanegara, Kalimantan } \quad \text { Timur. } & \text { NALARs, }\end{array}$ https://doi.org/10.24853/nalars.15.1.63-72

Pratomo, A., Soedwiwahjono, S., \& Miladan, N. (2019). Kualitas Taman Kota Sebagai Ruang Publik Di Kota Surakarta Berdasarkan Persepsi Dan Preferensi Pengguna. Desa-Kota, 1(1), 84. https://doi.org/10.20961/desakota.v1i1.12494.84-95

Rasidi, M. H., Jamirsah, N., \& Said, I. (2012). Urban Green Space Design Affects Urban Residents' Social Interaction. Procedia - Social and Behavioral Sciences, 68(November), 464-480. https://doi.org/10.1016/j.sbspro.2012.12.242

Rutledge, A. . (1981). A Visual Approach to Park Design. New York: Garland STPM Press.

Salayanti, S. (2017). TATA RUANG PERTUNJUKAN SEBAGAI SIMBOL INTERAKSI PEMAIN DENGAN PENONTON PADA SAUNG ANGKLUNG UDJO BANDUNG. Jurnal ATRAT, V5/N1/01/2017. 
Siahaan, James. (2010). Ruang Publik: Antara Harapan dan Kenyataan. Buletin tata Ruang, Edisi IV Juni - Juli: 11- 16. Jakarta: Badan Koordinasi Penataan Ruang Nasional.

Starke, B. ., \& Simonds, J. . (2013). Landscape Architecture: A Manual of Environmental Planning and Design. New York: Mc. Graw-Hill Bool Co. $\leftarrow$ Book

Sugiyanto, E., \& Sitohang, C. A. V. (2017). Optimalisasi Fungsi Ruang Terbuka Hijau Sebagai Ruang Publik Di Taman Ayodia Kota Jakarta Selatan. Jurnal Populis, 2(3), 205-218.

Taylor, L., \& Hochuli, D. F. (2017). Defining greenspace: Multiple uses across multiple disciplines. Landscape and Urban Planning, 158, 25-38. https://doi.org/10.1016/j.landurbplan.2016.09.024

Telecommunication Statistics in Indonesia 2015. (2015). Jakarta: Badan Pusat Statistik.

Tinarbuko, S. (2008). Semiotika Komunikasi Visual. Jalasutra.

Wibowo, A., \& Ritonga, M. (2018). Kebutuhan Pengembangan Standar Nasional Indonesia Fasilitas Taman Kota. Jurnal Standardisasi, 18(3), 161. https://doi.org/10.31153/js.v18i3.234

Widiastuti, K. (2013). Taman Kota Dan Jalur Hijau Jalan Sebagai Ruang Terbuka Hijau Publik Di Banjarbaru. Taman Kota Dan Jalur Hijau Jalan Sebagai Ruang Terbuka Hijau Publik Di Banjarbaru, 13(2), 57-64. https://doi.org/10.14710/mdl.13.2.2013.57-64

www.tribunjateng.com

Zhang, W., Yang, J., Ma, L., \& Huang, C. (2015). Factors affecting the use of urban green spaces for physical activities: Views of young urban residents in Beijing. Urban Forestry \& Urban Greening, 14(4), 851-857. https://doi.org/10.1016/J.UFUG.2015.08.006

Zoer'aini, I. (2005). Tantangan Lingkungan dan Lansekap Hutan Kota. Jakarta: Bumi Aksara. 